\title{
A METHOD OF ANAESTHESIA AND HYPOTHERMIA IN CEREBRAL VASCULAR SURGERY*
}

S. L. VANDEWATER, M.D., F R.C.P.(c) **, E. H. BotTereLL, M.D., F.R.C.s.(c) †, W. M. LOUGHEED, M.D.

THE application of hypotherraia to cerebral vascular surgery is the result of the physiological observation that a falling temperature, in the absence of shivering, results in a linear decrease in the total body oxygen consumption $(1,2)$. At $30^{\circ} \mathrm{C}$., the oxygen requirement of the body is about 50-60 per cent of normal. Lougheed and $\mathrm{Kahn}(3)$ have shown that this holds true for brain. At $25^{\circ} \mathrm{C}$., dogs can sustain a pernod of occlusion of all main cerebral vessels, or breathe 100 per cent cent nitrogen, for a period four times the normal, without irreversible brain tissue changes. On this basis, hypothermia is being used with and without hypotension to lower biam cellular metabolism to a point where occlusion of all circulation to the brain can be carried out for a reasonables period, if required. Reduced brain cell metabolism will tend to relieve arterial spasm and cerebral oedema associated particularly with ruptured berry aneurysms, and will allow complete control over the possibility of gross haemorrhage during the direct approach of an aneurysm, or excision of a large vascular tumour or arteriovenous malformation.

This Japer is manly concerned with the anaesthetic and cooling technique involvec., and with some of the problems arising in a series of 31 cases (Table I).

TABLE I

$\begin{array}{llr}\text { Neurosuhgical Cases under } & \text { Hypotherma } \\ 1 & \text { Berry aneurysms } & 23 \\ 2 & \text { A-V rialformations } & 5 \\ 3 & \text { Chordoma } & 1 \\ 4 & \text { Ghoblastoma } & 1 \\ 5 & \text { Hemispherectomy } & 1 \\ & & -31\end{array}$

The neurosurgical aspects and individual case reports will be reported in detail elsewhere.

\section{METHOD}

As there had been previous experience of the potentiation and sedative action of chlorpromazine (Largactil) $+\dagger$ in anaesthesia for general surgery (4), it has been used consistently in the series in combination with promethazine (Phenergan) $1 \uparrow$ and Demerol (Pethedine). These drugs were used for the purpose of

'Presented at the Annual Meeting, Canadian Anaesthetists' Society Toronto, Ont, June 22, 1955

* Department of Anaesthesia, Unversity of Toronto, and Toronto General Hospital tDepartment of Neurosurgery, University of Toronto, and Toronto General Hospital t†Supplied through the courtesy of Poulenc Limited, Montreal 
sedation, and to reduce the amount of other anaesthetic agents to a minimum, if not replace them. The incidental control of shivering has resulted.

1. Preoperative preparation. The diagnosis having been proven by angiography, and the decision to operate made, the patient is assessed by a cardiologist, and the state of the cardiovascular system noted; the investigation includes an E.C.G., E.E.G., and chest X-ray. It is to be noted that the majority of these patients are in the young-middle age group, and usually in good health except for their neurosurgical condition.

\section{Preoperative sedation}

(a) If the patent is conscious or semi-conscious, and time permits: chlorpromazine $50 \mathrm{mgm}$. promethazıne $50 \mathrm{mgm}$., intramuscularly in the evening.

chlorpromazine $50 \mathrm{mgm}$. promethazine $50 \mathrm{mgm}_{\text {. demerol }} 50 \mathrm{mgm}$., intramuscularly at 6.00 A.M. the day of operation.

(b) If the patient is unconscious, the above dosages are omitted.

(c) The patient is brought to the theatre at 7.00 A.M., usually in a state of sleep, if he was previously conscious. An intravenous drip of $250 \mathrm{cc}$. of normal saline is started, containing $50 \mathrm{mgm}$. each of chlorpromazine, promethazine, and demerol.

3. Induction of Anaesthesia. With the above preparation, the patient soon reaches a state of deep sleep. In the first ten cases, anaesthesia was then induced with thiopentone, but this has since been found unnecessary, and contraindicated, as discussed later. The patient is induced with $\mathrm{N}_{2} \mathrm{O} / \mathrm{O}_{2}$. After a small dose of succinylcholine, the trachea is sprayed with 5 per cent Cyclane, and intubation carried out, using a large Portex or Magill tube, without packing or cuff.

4. Anaesthesia. Anaesthesia is maintained throughout the operation with $\mathrm{N}_{2} \mathrm{O} / \mathrm{O}_{2}$ with or without minimal trichlorethylene using a 10-litre gas flow, nonrebreathing technique. As the temperature falls the trichlorethylene is continued, and the oxygen percentage increased from an unitial 30 per cent to $60-70$ per cent at the time the aneurysm is being dealt with. This provides a non-explosive anaesthetic with minimal resistance, and thus a slack brain. The patient is allowed to respire voluntarnly throughout, even down to $26^{\circ} \mathrm{C}$. as occurred in one case.

5. Cooling. The technique of surface cooling is used, with ice water. The patient, once anaesthetized, is placed in a stainless steel tank on the standard operating table designed by one of us (W M.L.) (5). He is not moved from this tank until the operation is completed. The tank construction is such that it allows the head to protrude out on a crutch head rest. During the first phase of the operation when the carotid and vertebral arteries are dissected in the neck and isolated for further use, ice is packed about the legs, thighs, abdomen, and lower chest. This usually requires $30-45$ minutes; the table is then placed in a horizontal position and cold water is added to the brim. The ice water is removed at $31-33^{\circ} \mathrm{C}$. allowing for a further drift to the desired final temperature of $29-30^{\circ}$.

6. Recording. A five-minute interval record of pulse, blood pressure, respirations, and temperature is made. A Cournand needle is inserted by the stab 
technique in the left radial artery (if a good ulnar pulse is present), and is connected to a simple aneroid manometer to continuously record the mean blood pressure. This also allows the taking of arterial blood samples for $\mathrm{pH}$ and oxygen estımations. The needle is also connected to a citrate-heyarin solution, to prevent clotting and thrombosis (the pulse is palpable after tie operation). A polyethylene tube is inserted in the jugular bulb for cerebral venous oxygen estimations.

Temperature recordings through a multiple lead thermocouple are made of rectal, thigh muscle, occasionally oesophagus, brain, and bath.

Skull E.E.G. leads are applied, for future use, and two leads of the E.E.G. are used for a continuous E.C.G. writer, and electromyograph (to detect shivering).

A Smith-Stone visual electrocardiography is in continuous use, and frequent multi-lead records are made (Fig. 1).

7. Shivering. In the series, shivering has occurred in two cases, and in each instance was controlled by the administration of $25 \mathrm{mgm}$. of chlorpromazine intravenously.

8. Induced hypotension. In five cases, the mean blood pressure was lowered to $30-50 \mathrm{~mm}$. Hg., using Arfonad in four and Hexamethonium bromide in one.



FIGURE 1 
9. Rewarming. If after the ice water has been removed, the patient's temperature continues to drift rapidly below $28^{\circ} \mathrm{C}$., then warm water, up to $33-35^{\circ}$, is added to the tank; otherwise it is left dry until the aneurysm is dealt with. Early in the series, water at $45^{\circ}$ was used to rewarm the patient, which invariably resulted in a severe tachycardia and hypotension, and in one case, a moderately severe leg burn. We now add water at a temperature not exceeding $35^{\circ} \mathrm{C}$. By the time the operation is finished, the rectal temperature has reached $31-32^{\circ}$, and the patient is removed from the tank, dried off, and allowed to rewarm further, entirely on his own, with only one covering sheet and no blankets. By this method, 6-8 hours elapse before the normal temperature is reached, and hyperthermia has not occurred.

\section{ObSeRvations}

1. Method of sedation. The use of chlorpromazine promethazine, and demerol in moderate doses, beginning several hours before operation, has provided a satisfactory state of sleep, free of any significant hypotension, sut sometimes accompanied by a moderate tachycardia. Induction of anaestlesia, omitting thiopentone, has been smooth, and intubation free of coughing and straming. $\mathrm{N}_{2} \mathrm{O} / \mathrm{O}_{2}$, trichlorethylene anaesthesia, has been adequate; shivering has occurred in two instances and was controlled by $25 \mathrm{mgm}$. of chlorpromazine.

2. Respirations. After stopping the use of thiopentone, the respiratory rate has never been below $15 / \mathrm{mm}$., even at $28^{\circ} \mathrm{C}$.; on the contrary, there is a tachypnoea, not necessarily due to the trichlorethylene as so little is used, but probably indicating the very light plane of anaesthesia. Tidal volumes have not been measured, but in the light of the $\mathrm{pH}$ changes we feel that the respirations were not depressed, or at least were adequate at the particular temperatures reached.

3. Blood pressure and pulse. A spontaneous hypotension has been the exception rather than the rule, but was a more prominent feature when thiopentone was used. The pulse rate follows no set pattern, and has varied from 36 to 140, but usually is in the 90-110 range. A sinus bradycardia responds to small doses of atropine, and a sinus tachycardia will slow with $1 \mathrm{cc}$. $1 / 2000$ prostigmine.

4. Cardiac arrhythmias. The occurrence of arrhythmias was frequent below $30^{\circ} \mathrm{C}$. (Table II).

TABLE II

E C G.-29 Cases Hypothermia

1 Sinus rhythm throughout

9

2 Preoperative auncular fibrillation which persisted 1 Auricular arrhythmias

3. Wandenng pace-maker

4 Aurncular tachycardia

5 Auricular flutter alone

6 Auricular flutter and aurıcular fibrillation

7 Auricular fibrillation

8. Ventricular fibrillation, preceded by auric fibrillation

Total 
We have the impression that arrhythmias were less frequent, and less significant, after thiopentone was omitted, as this has been the only change in the anaesthetic technique. Many of the arrhythmias were difficult to label with a name, and the electro-cautery caused some interference. Many of the arrhythmias occurred early in the cooling stage, and disappeared at the lower temperatures; others occurred at the lowest temperatures reached and disappeared on rewarming; still others persisted throughout. When arrhythmias did occur, hyperventilation with 100 per cent. oxygen made no appreciable change.

\section{CHANCE OF PH OF BLOOD DURING HYPOTHERMIA}

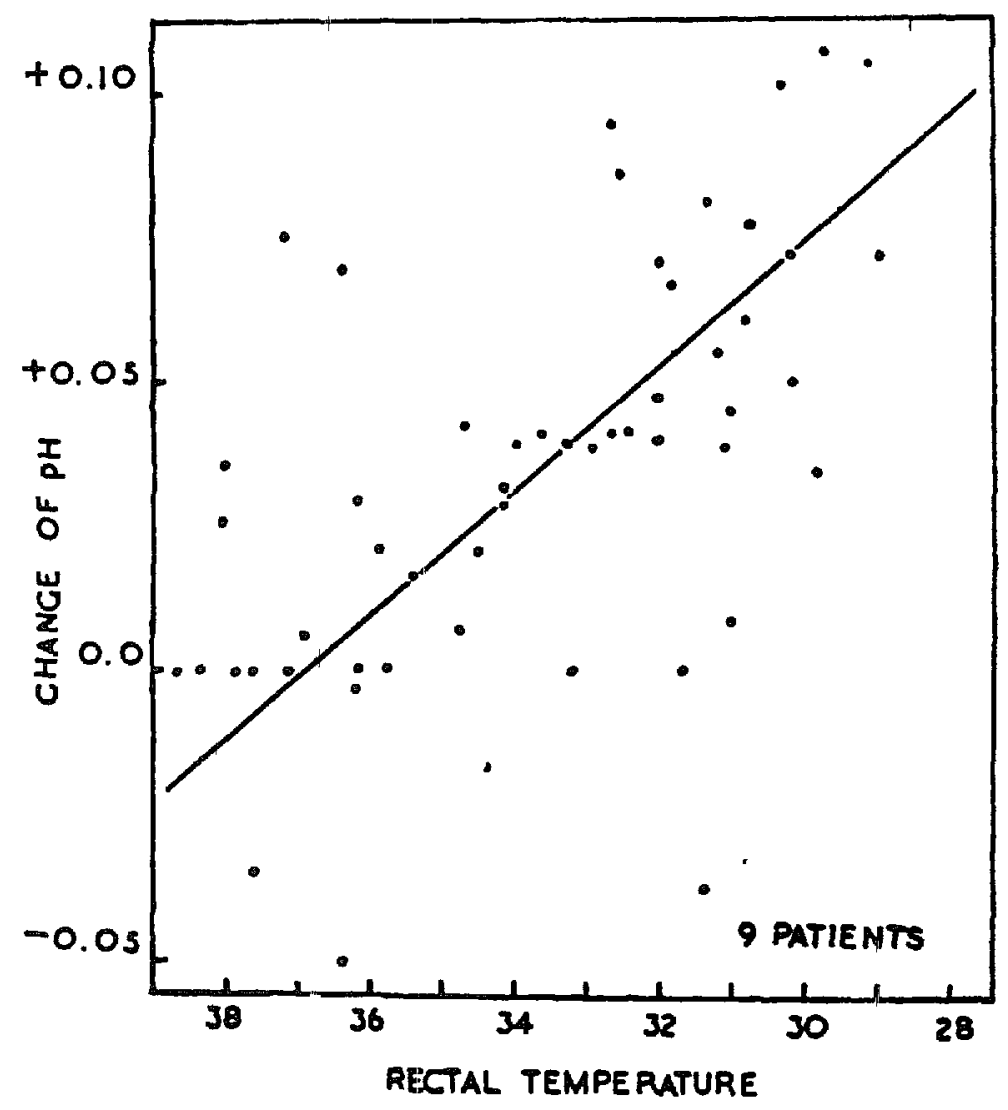

FIGURE 2

5. Arterial $p H$ Studies were made in the latter half of the series, and a scattergraph of readings made in nine aneurysms is shown (Fig. 2). It is to be noted that these readings are made on arterial blood, and adjusted to the blood temperature at the time the samples were taken. If the $\mathrm{pH}$ is given at $37^{\circ}$ an entirely different figure is obtained than the one which is readjusted to the initial temperature of the blood sample, e.g., at $30^{\circ} \mathrm{C}$. On this basis, our readings show a tendency towards alkaline $\mathrm{pH}$, rather than acid, as the temperature falls.

6. Cooling. The cooling of all the patients was successful, and without difficulty. The large obese patients of course required a longer time to reach the desired temperature, and showed a greater tendency to drift farther down, and to be slower to rewarm. Temperatures of the thigh muscle were taken to act as a guide 
as to how far and how fast the drift may be after removal of the ice water, as it represents a cold muscle mass, capable of further cooling the blood. We have not persisted in oesophageal or pharyngeal temperature readings. Cortical and intracerebral temperature readings have always been within $0.2^{\circ} \mathrm{C}$. of the rectal temperature. The cooling time varied from 30 to 90 minutes, and the lowest temperature range was from $26.0^{\circ}$ to $30.0^{\circ} \mathrm{C}$., with an average of $28.6^{\circ} \mathrm{C}$.

7. Recovery time. After the lesion has been dealt with, the patient breathes oxygen only, and all patients except those who were semi-conscious or unconscious prior to operation moved all four limbs before the last suture was in place. Two patients have been awake and talking coherently at $30^{\circ} \mathrm{C}$. Except for some neurosurgical reason, all patients were fully conscious by $33-34^{\circ} \mathrm{C}$.

\section{Results}

In the series of thirty-one cases, there have been four deaths, all occurring in the 23 aneurysms. The aneurysms have been summarzed in Table III.

TABLE III

\section{BerRy ANeurysms - 23 Castes}

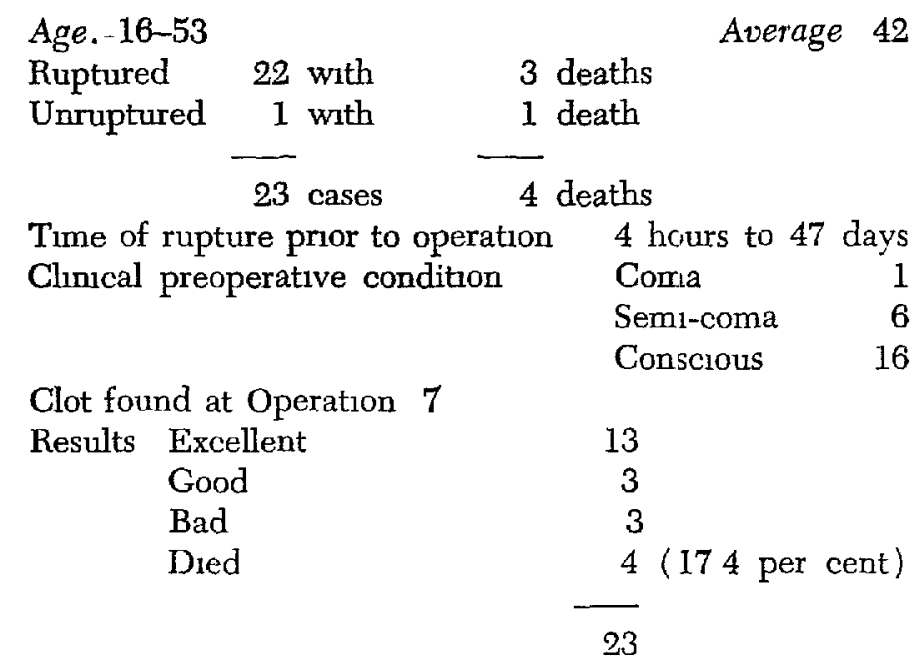

Of these four deaths, one can be attrubuted to the hypothermia, i.e. the patient died from irreversible ventricular fibrillation at: $28.3^{\circ} \mathrm{C}$. The cause of death in the other three cases was brain destruction from a massive preoperative haemorrhage, gross cerebral oedema due to preoperative softening from middle cerebral artery thrombosis, and secondary thrombosis of both anterior cerebral arteries.

The two cases of ventricular fibrillation occurred at $28.6^{\circ}$ and $28.3^{\circ} \mathrm{C}$ respectively: both patients were in their fifties, and both under induced hypotension with Arfonad. Their blood pressures at the time of onset of ventricular fibrillation were 78/55 and 66/35 respectively. One patient made a full recovery after a fifteen-minute interval of complete circulatory arrest (before cardiac massage was begun). The other did not respond to electrical defibrillation. Chemical defibrillation after Swan (6) was unsuccessful in both cases. 
All the patients other than those with aneurysms made a full and complete recovery from the operation.

There have been no complications to date from the intra-arterial needle punctures, and there has been no evidence of peripheral damage from surface cooling with ice and water.

\section{Discussion}

The technique of anaesthesia and cooling outlined above is adapted to neurosurgery, where the electro-cautery is required, and a slack brain is necessary. For that reason inflammable gases and the use of relaxants and controlled or even assisted respirations are avorded. Although there is considerable argument for controlled and even vigorous hyperventilation in the literature $(7,8)$, to prevent acıdemia, presumably from $\mathrm{CO}_{2}$ accumulation, ovr observations, from the above technique, do not bear this argument out. It seems reasonable to suppose that under light enaesthesia in the absence of known respiratory depressants, $\mathrm{CO}_{2}$ production parallels $\mathrm{O}_{2}$ utilization, and that respirations at least down to $26^{\circ} \mathrm{C}$ are adequate to clear $\mathrm{CO}_{2}$. Our $\mathrm{pH}$ studies even suggest a hyperventulation with a tendency towards alkalemia.'

The occurrence of cardiac arrhythmias is frequent, but their significance in many cases is questionable. The difficulty hes in recognizing the potentially dangerous arrhythmias, and then deciding what to do: rewarm, or sit tight and watch. We have a tendency to follow the latter course.

The results with aneurysmis have been particularly promising as the mortality rate from initial or recurrent haemorrhage is high under conservative treatment.

\section{SUMMARY}

A method of anaesthesia and surface cooling as we have used it in 31 neurosurgical cases including 23 aneurysms has been outlined. The neurosurgical detalls and case reports will be dealt with elsewhere. Observations on the operative course and some of the problems have been given.

\section{Addendum}

Since this paper was given, three other cases of ruptured berry aneurysms have been dealt with under hypothermia. All patients made an excellent recovery.

\section{RÉSUMÉ}

L'auteur décrit une méthode d'anesthésie avec hypothermie en chirurgie vasculaure et en rapporte 31 cas. De ceux-ci, 23 étaient des aneurismes cérébraux dont 22 étaient déjà rupturés.

L'anesthésie comporte des injections intra musculaires répetées données avant l'opératıon, de chlorpromazène (Largactıl) de Prométhazine (Phenergan) et de Démérol, suivies de protoxyde d'azote, oxygene et trichlorethylène. Aucun barbiturıque est injecté en intra-veineuse et le patient respire par lui-même durant toute l'intervention. Dans 9 cas, on a étudié le $\mathrm{pH}$ arterial qui montre une tendance à l'alkalose lorsque le patient refroidit par suite de la méthode anesthésique employée. 
L'hypothermie est obtenue par un refroidissement de surface avec eau glacée dans un bain métallique dans lequel on garde le patient durant l'opération. Les moyennes de température obtenues son entre $28^{\circ}-29^{\circ} \mathrm{C}$. La plus basse était $26.1^{\circ} \mathrm{C}$.

Il y eut 4 mortalités dans cette série dont une présentant une fibrillation ventriculaire irréversible attribuable à l'hypothermie.

\section{REFERENCES}

1. Bigelow, W. G., Lindsay, W K, Harmison, R. C, Gohdon, R A \& Greenwood, W F. Oxygen Transport and Utulization in Dogs at Low Body Temperature Am J. Physiol. 160. 125 (Jan. 1950).

2 Lynn, R B., Melrose, D G, Churchill-Davidson, H C. \& McMillan, I. K R. Hypothermia: Further Observations on Surface Coolng. Ann Roy Coll Surg 14267 (1954).

3. LougheED, W. M. \& KAHN, D. S Curcumvention of Anoxna durmg Arrest of Cerebral Circulation for Intracranial Surgery J. Neurosurg 12(3) 226 (1955)

4. Vandewater, S. L. \& Gondon, R A. Largactil in Anaesthesia Canad Anaes Soc J. 2. 23 (Jan. 1955).

5. Lougheed, W. M., Sweet, W. H, White, J. C \& Brewsten, W. $R$ The Use of Hypotherma in Surgical Treatment of Cerebral Vascular Lesions J. Neurosurg. 12(3). 240 1955).

6. Zeavin, I., Vmtue, R. W \& Swan, R. Cessation of Circulation in General Hypothermia. II. Anaesthetic Management Anesthesiology 51(2) 113 (March 1954).

7. Ross, D. N. Physiological Observations during Hypothermia Guy's Hosp Rep. 103. 116 (1954).

8. Swan, H., Zeavin, I, Blount, S. G. \& Virtue, R W. Surgery by Durect Vision in the Open Heart during Hypothermia. J. A. M. A., 153. 1081 (1953). 